\title{
NRIP3 wt Allele
}

National Cancer Institute

\section{Source}

National Cancer Institute. NRIP3 wt Allele. NCI Thesaurus. Code C126615.

Human NRIP3 wild-type allele is located in the vicinity of $11 \mathrm{p} 15.3$ and is approximately 23

$\mathrm{kb}$ in length. This allele, which encodes nuclear receptor-interacting protein 3, may be involved in the modulation of nuclear receptor activity. 